\title{
Quality assessment of gluten-free bread from pro-vitamin A cassava and velvet bean flour
}

\author{
Olatunde, S.J., Odebunmi, O.F., *Abioye, V.F. and Oladimeji, T.E. \\ Department of Food Science, Ladoke Akintola University of Technology, Ogbomoso, Nigeria
}

Article history:

Received: 23 May 2020

Received in revised form: 1

June 2020

Accepted: 8 June 2020

Available Online: 29 July

2020

\section{Keywords:}

Gluten-free bread,

Pro-vitamin A cassava,

Velvet beans,

Coeliac disease

\section{DOI:}

https://doi.org/10.26656/fr.2017.4(6).243

\begin{abstract}
The increasing trend of coeliac disease (CD) and gluten-related disorders has led to consumers' increasing interest in gluten-free products with quality characteristics similar to wheat bread. The potentials of pro-vitamin A cassava and velvet bean in the production of nutritious gluten-free bread was investigated. Different levels of flour formulations $(100: 0,90: 10,80: 20,70: 30,60: 40$ and 50:50 (w/w), respectively) were obtained from provitamin A cassava and velvet beans flours while xanthan gum was used as the bread improver. The effect of the addition of velvet beans flour to pro-vitamin A cassava on proximate content, anti-nutritional and functional properties of the flour were determined, while the physical and the sensory properties of the bread samples were evaluated. The protein, ash, fat and energy values were in the ranges of $1.51-23.00 \%, 1.12-3.35 \%, 2.35-$ $12.50 \%$ and $1555.34-1760 \mathrm{~kJ} / 100 \mathrm{~g}$, respectively. The water absorption capacity, bulk density, swelling capacity and wettability were in the ranges of $27.69-32.35 \%, 1.48$ $1.61 \%, 1.01-1.15 \mathrm{~g} / \mathrm{mL}$ and 9.44-35.19 min, respectively. The values obtained for $\mathrm{HCN}$, tannin, phytate, Dopamine were 0.64-0.88, 2.22-3.55 mg/100 g, 0.48-1.41 mg/100 g, 0.00$4.11 \mathrm{ng} / \mathrm{mL}$, respectively. The physical properties ranged $640-980 \mathrm{~cm}^{3}, 371-544 \mathrm{~g}, 1.73-$ $2.10 \mathrm{~cm}^{3} / \mathrm{g}$ and $0.20-1.40 \mathrm{~cm}$ for loaf volume, loaf weight, specific volume and oven spring, while the sensory evaluation indicated better acceptability at $30 \%$ velvet bean flour substitution. This research has shown that nutrient-dense gluten-free bread with acceptable sensory quality can be produced from pro-vitamin A cassava and velvet beans. This has potentials to address the coeliac disease.
\end{abstract}

\section{Introduction}

Coeliac disease (CD), an intolerance of gluten, is prevalent and as high as one in 200 of the world population (Fasano and Catassi, 2001). Wheat which is the major flour used in production bread, a significant source of food in Nigeria has gluten. The possible way to overcome this problem is to search for the native crop sources which could be substituted for the wheat flour. Therefore, there is a trend in the use of locally produced crops such as faba bean, lupin, quinoa, buckwheat, rice, cassava among others in bakery products (Lopez et al., 2004; Torbica et al., 2010; Abou-Zaid et al., 2011)

Cassava is one of the most important tropical root crops in developing countries and Its starchy roots are a major source of dietary energy for more than 500 million people (FAO, 2005). It is known to be the highest producer of carbohydrates among staple crops. Cassava tubers generally possess a cream or white flesh colour and do not contain a significant amount of carotenoids.
However, the advent of yellow root cassava will complement current efforts (such as pill supplementation, food fortification etc) to address VAD by delivering vitamin A through a staple food. Vitamin A remains a very important component of human nutrition, as it aids in vision, cell differentiation, synthesis of glycoprotein, reproduction and overall growth and development (Njoku et al., 2014)

Velvet bean (Mucuna pruriens), belongs to the Fabaceae family, it is part of various legumes which is not commonly used by people as a result of antinutrients. Velvet bean is commonly grown in the tropical and subtropical part of the world. It has been reported to be a great source of dietary protein because it has a higher percentage of protein (about 26\%), and it is easily digestible compared to other annual leguminous crops (Janardhanan et al., 2003). Velvet bean can also help in stress management and improvement of semen quality (Shukla, 2007). One of the possible ways to promote the 
use of velvet bean could be its utilization in formulations for mass consumer goods, such as bread.

Bread is an important baked stable food, the consumption of which is steady and ever-increasing in Nigeria (Olaoye et al., 2006). Several researchers have worked to promote the use of composite flours in which flour from locally grown crops and high protein seeds replace a portion of wheat flour for use in bread. This has led to a decrease in the demand for imported wheat to produce protein-enriched bread (Giami et al., 2004). However, there is scanty information on an attempt to produce gluten-free bread especially from under-utilized legume like velvet bean. In view of the above background, this study was aimed at producing glutenfree bread using pro-vitamin A cassava and velvet bean flour as an alternative to wheat bread.

\section{Materials and methods}

\subsection{Materials}

Pro-vitamin A cassava (TMS 01/1368 variety) was obtained from Oyo State Agricultural Development Farm, Ogbomoso, Oyo State, Nigeria. Velvet bean was obtained from a local farm in Ogbomoso. Other ingredients: yeast, salt, sugar, fat, ascorbic acid and Xanthan gum were procured from a local market in Lagos, Nigeria.

\subsection{Production of pro-vitamin A cassava flour}

High-quality flour was produced from pro-vitamin A cassava tuber as described by Nwosu et al. (2014). Fresh cassava tubers were washed to remove the adhering dirt and sand from the root surface and then peeled. Cassava tubers were peeled manually using knives, washed and reduced in size by grating using a locally fabricated grating machine. This was then pressed to squeeze out as much of the water as possible, dried for 8 hours at $60^{\circ} \mathrm{C}$, milled into flour and sieved $(300 \mu \mathrm{m})$.

\subsection{Preparation of velvet beans into flour}

Velvet beans were processed into flour as described by Balogun and Olatidoye (2010). About $1000 \mathrm{~g}$ of matured velvet beans were sorted, cleaned to remove extraneous materials like stones and defective seeds, soaked in distilled water $(1: 4 \mathrm{w} / \mathrm{v})$ for $48 \mathrm{hrs}$ at ambient temperature $\left(27 \pm 2^{\circ} \mathrm{C}\right)$ to reduce the anti-nutrients present in Velvet beans. It was dehulled manually, oven-dried at $60^{\circ} \mathrm{C}$ for $24 \mathrm{hrs}$ and milled into flour $(300 \mu \mathrm{m})$.

\subsection{Preparation of bread}

The bread was produced according to the method described by Edema et al. (2005) with slight modification. Pro-vitamin A Cassava Flour (PVACF) was mixed with Velvet Beans Flour (VBF) in the ratio of 90:10, 80:20, 70:30, 60:40 50:50 w/w. PVACF: VBF at 100:0 and 0:100 levels were used as control. The bread recipe consisted of $100 \mathrm{~g}$ of each flour blend, $15 \mathrm{~g}$ sugar, $18 \mathrm{~g}$ xanthan gum, $2.0 \mathrm{~g}$ salt, $10.0 \mathrm{~g}$ margarine, $15 \mathrm{~g}$ yeast, $2.0 \mathrm{~g}$ nutmeg, $7.0 \mathrm{~mL}$ EDC oil and $150 \mathrm{~mL}$ of water. The dough was kneaded with kneading machine, molded and transferred into baking pans greased with fats. The dough was allowed to rise at room temperature $\left(27 \pm 2^{\circ} \mathrm{C}\right)$ in the baking pan, proofed and baked $\left(210^{\circ} \mathrm{C}\right.$, 33 mins). It was allowed to cool then packaged for further analyzes.

\subsection{Formulation of samples}

The ratios of pro-vitamin A cassava and velvet beans flour blends were as presented in Table 1.

Table 1. Sample code and formulated ratio of flour blends

\begin{tabular}{ccc}
\hline Sample & $\begin{array}{c}\text { Pro-vitamin A cassava } \\
\text { flour (\%) }\end{array}$ & $\begin{array}{c}\text { Velvet beans flour } \\
(\%)\end{array}$ \\
\hline A & $100 \%$ & - \\
B & $90 \%$ & $10 \%$ \\
C & $80 \%$ & $20 \%$ \\
D & $70 \%$ & $30 \%$ \\
E & $60 \%$ & $40 \%$ \\
F & $50 \%$ & $50 \%$ \\
G & - & $100 \%$ \\
\hline
\end{tabular}

\subsection{Analysis}

\subsubsection{Proximate composition of flour}

Moisture, fat, ash, crude fibre, protein contents of the flour blends were determined as described by AOAC (2010) methods and total carbohydrate was calculated by difference. The beta- carotene was determined as described by Kumar et al. (2011).

\subsubsection{Anti-nutritional factor}

Total hydrogen cyanide was determined using Ikediobi et al. (1980). The phytic acid content was determined by Latta and Eskin (1980) method and the tannin content was determined by the method as described by Makkar et al. (2009). L-Dopa was determined by the method described by Brain (1976).

\subsubsection{Physical properties of bread produced}

The loaf volume was measured by rapeseed displacement method as modified by Giami et al. (2004). The weight of the loaf was determined using a weighing scale. The specific volume was determined by dividing the loaf volume with its corresponding loaf weight. The oven spring for each bread sample was determined from the difference in height of each dough before and after 
baking.

\subsubsection{Functional properties of the flour}

The bulk density and water absorption capacity of the flour was determined according to the method that was described by Giami et al. (1992). The wettability of the flour samples was determined by Onwuka (2005). The swelling index was determined according to the method described by Nwosu et al. (2014).

\subsection{Sensory evaluation of gluten-free bread}

Consumer's acceptability of bread was conducted using 20 semi-trained panelists consisting of students of Ladoke Akintola University Technology, Ogbomoso, Nigeria. Most panelists were between the ages: 18-30 years and a 9-point hedonic scale ranging from 9=liked extremely to $1=$ disliked extremely, was used.

\subsection{Statistical analysis}

All experiments including organoleptic analyses were replicated. The means and standard deviations (SD) were calculated taking all the readings into consideration. Statistical analysis was performed using SPSS (Statistical Package for Social Sciences, version 20). One-way ANOVA (Analysis of variance at the level of significance $p \leq 0.05$ ) was performed using Duncan multiple range tests to ascertain the significance of the means.

\section{Results and discussion}

\subsection{Nutritional composition of blends of pro-vitamin A} cassava flour and velvet bean flour

The result of the proximate compositions of the blend of PVACF and velvet beans is as shown in Table 2. The moisture content ranged from $4.18 \%$ to $6.80 \%$ with $100 \%$ PVACF as the sample with the lowest moisture content and the VBF had the highest. There was no significant difference $(p>0.05)$ in the moisture content of the sample from $100 \%$ PVACF up till $50 \%$ inclusion of VBF. The moisture content is close to the value reported for the moisture content of velvet beans $(6.02 \%)$ (Balogun and Olatidoye, 2012). The protein content ranged from $1.51 \%$ to $23 \%$. There was an elevated increment in the protein content due to the incorporation of velvet beans in the flour mixes. The protein content of $100 \%$ velvet beans flour $(20.17 \%)$ agrees with the value (20.2-29.3\%) reported by Vadivel and Janardhanan (2000).

The ash content ranged from $1.59 \%$ to $3.35 \%$ (Table 2). Sample A (100\% PVACF) had the least Ash content while $100 \%$ velvet beans had the highest Ash content. The ash content increased with the increase in the inclusion of velvet beans, this could be a reflection of the high mineral content in velvet beans. The amount of ash recorded $(3.35 \%)$ for velvet beans flour was higher than the value reported for cooked velvet bean $(2.31 \%)$ by Ifesan et al. (2017). This might not be unconnected to processing difference as cooking would have leached some nutrients. The fat content ranged from $2.33 \%$ to $14.45 \%$ (Table 2). There is a general increase in fat content with an increase in the level of VBF inclusion. The fat content of $100 \%$ velvet beans flour $(12.50 \%)$ was lower than the value (14.50) reported by Balogun and Olatidoye (2012). This might not be unconnected with the varietal differences. The crude fibre content ranged from $3.39 \%$ to $6.55 \%$ with $100 \%$ pro-vitamin A cassava having the highest fibre content of $6.55 \%$, followed by $100 \%$ velvet beans flour. This is close to the range of value reported by Balogun and Olatidoye (2012). The calorific value ranged from $1555.34 \mathrm{~kJ} / 100 \mathrm{~g}$ to 1760.83 $\mathrm{kJ} / 100 \mathrm{~g}$. The calorific value of $100 \%$ velvet beans flour $(1718.16 \mathrm{~kJ} / 100 \mathrm{~g})$ agrees with the value (1703.95 $\mathrm{kJ} / 100 \mathrm{~g}$ ) as reported by Balogun and Olatidoye (2012).

The carbohydrate content ranged from $50.31 \%$ to $84.32 \%$ with flour composition of $100 \%$ PVACF having the highest carbohydrate content. It appears that velvet beans have a high range of carbohydrate $(50.31 \%$ to $84.32 \%$ ), because of their low-fat content.

Table 2. Proximate Composition and Energy value of blends of Pro-vitamin A cassava and velvet bean flours

\begin{tabular}{cccccccc}
\hline Sample & Moisture (\%) & Crude protein & Ash (\%) & Fat (\%) & Crude fibre (\%) & CHO (\%) & Caloric value \\
\hline A & $4.18 \pm 0.08^{\mathrm{b}}$ & $1.51 \pm 0.67^{\mathrm{c}}$ & $1.12 \pm 0.13^{\mathrm{b}}$ & $2.33 \pm 0.74^{\mathrm{b}}$ & $6.55 \pm 0.44^{\mathrm{a}}$ & $84.32 \pm 0.16^{\mathrm{a}}$ & $1714.37 \pm 19.42^{\mathrm{a}}$ \\
B & $4.63 \pm 1.12^{\mathrm{b}}$ & $16.39 \pm 0.41^{\mathrm{b}}$ & $1.59 \pm 0.01^{\mathrm{c}}$ & $3.03 \pm 1.31^{\mathrm{c}}$ & $4.72 \pm 0.25^{\mathrm{ab}}$ & $69.65 \pm 2.59^{\mathrm{b}}$ & $1655.76 \pm 12.87^{\mathrm{b}}$ \\
C & $5.57 \pm 0.06^{\mathrm{b}}$ & $18.55 \pm 0.63^{\mathrm{b}}$ & $1.95 \pm 0.23^{\mathrm{bc}}$ & $3.21 \pm 0.13^{\mathrm{d}}$ & $3.39 \pm 0.69^{\mathrm{b}}$ & $67.37 \pm 1.16^{\mathrm{ab}}$ & $1555.34 \pm 3.95^{\mathrm{c}}$ \\
D & $4.86 \pm 0.44^{\mathrm{b}}$ & $21.29 \pm 2.05^{\mathrm{a}}$ & $1.98 \pm 0.05^{\mathrm{bc}}$ & $12.10 \pm 0.35^{\mathrm{b}}$ & $3.58 \pm 0.01^{\mathrm{b}}$ & $56.19 \pm 2.02^{\mathrm{c}}$ & $1749.98 \pm 13.70^{\mathrm{a}}$ \\
E & $5.04 \pm 1.03^{\mathrm{ab}}$ & $22.71 \pm 1.03^{\mathrm{a}}$ & $2.82 \pm 0.22^{\mathrm{a}}$ & $14.45 \pm 2.05^{\mathrm{a}}$ & $4.57 \pm 1.56^{\mathrm{ab}}$ & $50.43 \pm 2.77^{\mathrm{d}}$ & $1747.52 \pm 48.15^{\mathrm{a}}$ \\
F & $5.48 \pm 0.54^{\mathrm{b}}$ & $23.00 \pm 0.16^{\mathrm{a}}$ & $2.98 \pm 0.27^{\mathrm{a}}$ & $14.18 \pm 0.68^{\mathrm{a}}$ & $3.94 \pm 0.64^{\mathrm{b}}$ & $50.31 \pm 0.35^{\mathrm{d}}$ & $1760.83 \pm 17.05^{\mathrm{a}}$ \\
G & $6.80 \pm 1.62^{\mathrm{a}}$ & $20.17 \pm 0.47^{\mathrm{b}}$ & $3.35 \pm 0.19^{\mathrm{a}}$ & $12.50 \pm 0.63^{\mathrm{ab}}$ & $5.46 \pm 1.35^{\mathrm{ab}}$ & $51.73 \pm 0.31^{\mathrm{d}}$ & $1718.16 \pm 21.26^{\mathrm{a}}$ \\
\hline
\end{tabular}

Means in the same column with the same superscript are not significantly different ( $\mathrm{p}>0.05)$. A - $100 \%$ PVACF, B - 90\%:10\% PVACF/VBF, C - 80\%:20\% PVACF/VBF, D - 70\%:30\% PVACF/VBF, E - 60\%:40\% PVACF/VBF, F - 50\%:50\% PVACF/ $\mathrm{VBF}$, and $\mathrm{G}-100 \% \mathrm{VBF}$ 


\subsection{Functional properties of flour blends}

The functional properties of the flour blends are presented in Table 3 . The bulk density of the samples ranged from 1.34 to $1.61 \mathrm{~g} / \mathrm{cm}^{3}$. Flour blend 60PVACF:40VBF had the highest value, while 00PVACF:100VBF had the least value. The bulk density of a food material is important in relation to its packaging requirement (Adebowale et al., 2012). Increase in bulk density offers greater packaging advantage as greater quantity may be packed within the constant volume (Wahab et al., 2016). The Water Absorption Capacity (WAC) of the blends was between $24.45 \%$ and $32.35 \%$. There was a decreasing trend in the values with the increasing level of velvet flour beans. The decreased trend in the WAC of the composite flours might be attributed to the presence of hydrophobic amino acids which interferes with the ability of the PVCF starch to absorb water (Kaur and Singh, 2005). WAC is the ability of a product to associate with water under limiting conditions (Singh, 2001). It has been suggested that flours with such high WAC as seen in this study will be very useful in bakery products, as this could prevent staling by reducing moisture loss. Swelling capacity varied between 1.01 and $1.27 \mathrm{~g} / \mathrm{mL}$. swelling power is influenced by amylose and amylopectin characteristics, the interaction between the water molecules and the flour starch chains in the amorphous and crystalline areas
(Chan et al., 2009).

The wettability of the flours ranged from 9.44 mins to $35.19 \mathrm{~min}$. However, the wettability from Table 3 clearly showed that sample A $(100 \%$ PVACF) at a significant level $(\mathrm{p}<0.05)$ had the lowest wettability 9.44 mins compared to other which have an inclusion of velvet beans flour. The wettability results implied that pro-vitamin A flour required longer time than the other flour samples before it became completely wet

\subsection{Anti-nutritional factors of flour blends}

Significant $(p<0.05)$ difference existed for HCN, tannin, phytate, oxalate, and dopamine contents of the composite flour blends as shown in Table 4. The Hydrogen Cyanide (HCN) content value ranged from 0.64 to $0.88 \mathrm{ppm}$. The value of the HCN is within the acceptable cyanide level in the flour blend. Aluko (2004) affirmed that the maximum acceptable level of cyanide in cassava flour is $10 \mathrm{ppm}$ of cassava flour. The tannin values which ranged from $2.22 \mathrm{mg} / 100 \mathrm{~g}$ in sample $\mathrm{G}$ (100\% velvet beans flour) to $3.55 \mathrm{mg} / 100 \mathrm{~g}$ in sample $\mathrm{F}$ (50:50\% PVACF/VBF) increased as the percentage of VBF increased. Tannins are present in virtually all parts of plants and are known to inhibit trypsin, chymotrypsin, amylase, and lipase activities (Inyang and Ekop, 2015). The phytate content which varied from $0.48 \mathrm{mg} / 100 \mathrm{mg}$ in sample A (100\% PVACF) to $1.41 \mathrm{mg} / 100 \mathrm{~g}$ in sample

Table 3. Functional properties of blends of pro-vitamin A cassava flour and velvet beans flour

\begin{tabular}{ccccc}
\hline Sample & $\%$ WAC & BD $\left(\mathrm{g} / \mathrm{cm}^{3}\right)$ & $\mathrm{SC}(\mathrm{g} / \mathrm{mL})$ & WB $(\mathrm{min})$ \\
\hline A & $32.35 \pm 0.02^{\mathrm{a}}$ & $1.51 \pm 0.01^{\mathrm{c}}$ & $1.15 \pm 0.01^{\mathrm{c}}$ & $9.44 \pm 0.03^{\mathrm{g}}$ \\
B & $31.10 \pm 0.03^{\mathrm{b}}$ & $1.57 \pm 0.01^{\mathrm{b}}$ & $1.27 \pm 0.01^{\mathrm{a}}$ & $14.49 \pm 0.00^{\mathrm{f}}$ \\
C & $29.18 \pm 0.03^{\mathrm{d}}$ & $1.53 \pm 0.01^{\mathrm{c}}$ & $1.14 \pm 0.01^{\mathrm{cd}}$ & $28.44 \pm 0.06^{\mathrm{d}}$ \\
D & $29.86 \pm 0.03^{\mathrm{c}}$ & $1.48 \pm 0.01^{\mathrm{d}}$ & $1.11 \pm 0.01^{\mathrm{d}}$ & $35.19 \pm 0.10^{\mathrm{a}}$ \\
E & $27.79 \pm 0.02^{\mathrm{f}}$ & $1.61 \pm 0.01^{\mathrm{a}}$ & $1.01 \pm 0.01^{\mathrm{f}}$ & $33.32 \pm 0.03^{\mathrm{b}}$ \\
F & $27.69 \pm 0.03^{\mathrm{e}}$ & $1.54 \pm 0.01^{\mathrm{c}}$ & $1.07 \pm 0.01^{\mathrm{e}}$ & $29.35 \pm 0.01^{\mathrm{c}}$ \\
G & $24.45 \pm 0.03^{\mathrm{g}}$ & $1.34 \pm 0.01^{\mathrm{e}}$ & $1.23 \pm 0.01^{\mathrm{b}}$ & $16.19 \pm 0.00^{\mathrm{e}}$ \\
\hline
\end{tabular}

Means in the same column with the same superscript are not significantly different ( $\mathrm{p}>0.05)$. A - 100\% PVACF, B - 90\%:10\% $\mathrm{PVACF} / \mathrm{VBF}, \mathrm{C}-\mathrm{80} \%: 20 \% \mathrm{PVACF} / \mathrm{VBF}, \mathrm{D}-70 \%: 30 \% \mathrm{PVACF} / \mathrm{VBF}, \mathrm{E}-60 \%: 40 \% \mathrm{PVACF} / \mathrm{VBF}, \mathrm{F}-50 \%: 50 \% \mathrm{PVACF} /$ VBF, and G - 100\% VBF. WAC: Water Absorption Capacity, BD: Bulk Density, SC: Swelling Capacity, and WB: Wettability

Table 4. Anti-nutritional factor of blends of Pro-vitamin A cassava and velvet beans flours

\begin{tabular}{ccccc}
\hline Sample & HCN $(\mathrm{ppm})$ & Tannin $(\mathrm{mg} / 100 \mathrm{~g})$ & Phytate $(\mathrm{mg} / 100 \mathrm{~g})$ & Dopamine $(\mathrm{ng} / \mathrm{mL})$ \\
\hline A & $0.68 \pm 0.01^{\mathrm{cd}}$ & $2.44 \pm 0.01^{\mathrm{d}}$ & $0.48 \pm 0.00^{\mathrm{e}}$ & $0.00 \pm 0.00$ \\
B & $0.70 \pm 0.01^{\mathrm{c}}$ & $2.46 \pm 0.10^{\mathrm{d}}$ & $1.37 \pm 0.00^{\mathrm{d}}$ & $0.06 \pm 0.01^{\mathrm{e}}$ \\
C & $0.70 \pm 0.01^{\mathrm{c}}$ & $2.49 \pm 0.03^{\mathrm{cd}}$ & $1.40 \pm 0.00^{\mathrm{bc}}$ & $0.43 \pm 0.01^{\mathrm{d}}$ \\
D & $0.81 \pm 0.00^{\mathrm{b}}$ & $2.59 \pm 0.01^{\mathrm{c}}$ & $1.41 \pm 0.00^{\mathrm{a}}$ & $0.46 \pm 0.03^{\mathrm{d}}$ \\
E & $0.82 \pm 0.04^{\mathrm{b}}$ & $2.72 \pm 0.01^{\mathrm{b}}$ & $1.40 \pm 0.00^{\mathrm{bc}}$ & $0.65 \pm 0.06^{\mathrm{c}}$ \\
F & $0.88 \pm 0.03^{\mathrm{a}}$ & $3.55 \pm 0.03^{\mathrm{a}}$ & $1.41 \pm 0.00^{\mathrm{a}}$ & $3.09 \pm 0.06^{\mathrm{b}}$ \\
G & $0.64 \pm 0.00^{\mathrm{d}}$ & $2.22 \pm 0.03^{\mathrm{e}}$ & $1.41 \pm 0.00^{\mathrm{a}}$ & $4.11 \pm 0.00^{\mathrm{a}}$ \\
\hline
\end{tabular}

Means in the same column with the same superscript are not significantly different ( $\mathrm{p}>0.05)$. A $-100 \% \mathrm{PVACF}, \mathrm{B}-90 \%: 10 \%$ $\mathrm{PVACF} / \mathrm{VBF}, \mathrm{C}-80 \%: 20 \% \mathrm{PVACF} / \mathrm{VBF}, \mathrm{D}-70 \%: 30 \% \mathrm{PVACF} / \mathrm{VBF}, \mathrm{E}-60 \%: 40 \% \mathrm{PVACF} / \mathrm{VBF}, \mathrm{F}-50 \%: 50 \% \mathrm{PVACF} /$ $\mathrm{VBF}$, and $\mathrm{G}-100 \% \mathrm{VBF}$ 
G generally increased as the inclusion of VBF increased. Velvet beans are rich in phytate and the presence of this compound may reduce the bioavailability of minerals such as iron, magnesium, calcium in the flour blends. Dopamine, a precursor of L-DOPA, ranged from 0.06 $\mathrm{ng} / \mathrm{mL}$ to $4.11 \mathrm{ng} / \mathrm{mL}$, it increased as the level of VBF inclusion increased. L-Dopa is a potent neurotransmitter precursor which is reported to be responsible for the toxicity of the Mucuna seeds (Lorenzetti et al., 1998). The values obtained were within the acceptable level as reported by Siddhuraju et al. (2000).

\subsection{Physical properties of bread samples}

Table 5. Loaf weight, loaf volume, specific volume and oven spring of the bread produced

\begin{tabular}{|c|c|c|c|c|}
\hline Samples & 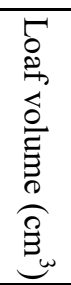 & 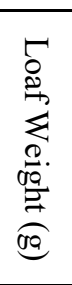 & 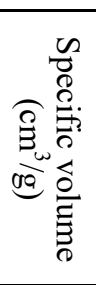 & 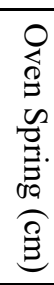 \\
\hline A & 640 & 371 & 1.73 & 0.2 \\
\hline B & 750 & 425 & 1.76 & 0.3 \\
\hline $\mathrm{C}$ & 820 & 460 & 1.78 & 0.5 \\
\hline D & 930 & 534 & 1.74 & 0.8 \\
\hline $\mathrm{E}$ & 970 & 544 & 1.78 & 1.1 \\
\hline $\mathrm{F}$ & 990 & 471 & 2.1 & 1.4 \\
\hline
\end{tabular}

A - $100 \%$ PVACF, B - 90\%:10\% PVACF/VBF, C - 80\%:20\% PVACF/VBF, D - 70\%:30\% PVACF/VBF, E - 60\%:40\% PVACF/VBF, F - 50\%:50\% PVACF/VBF, and G - 100\% VBF

The physical properties of the flour samples are as shown in Table 5. The volume, weight, specific volume and oven spring of loaf samples ranged from 640 to 990 $\mathrm{cm}^{3}, 371.0$ to $544.0 \mathrm{~g}, 1.73$ to $2.10 \mathrm{~mL} / \mathrm{g}$ and 0.20 to 1.40, respectively. The loaf volume increased proportionately with the increase in VBF in the formulation. The weight of the loaves increased with increase in VBF. This might be a result of the formation of a gel network during oven heating that strengthens the expanding cells of the dough and, as a result, improves gas retention and bread volume (Bell, 1990). The
Specific loaf volume increased with increase in VBF in the formulation. The high oven spring recorded by the composite bread samples could be attributed to xanthan gum content which has a direct contribution to the viscoelastic properties of the dough (Okaka, 2005). The loaf volume and oven spring are good indicators of the crumb, how light and airy the interior of the bread are. The lower crumb value indicates a dense and compact crumb while the higher value indicates how loose and airy the crumbs are (Nwosu et al., 2014).

\subsection{Sensory evaluation of the bread samples}

The aroma, taste, texture and overall acceptability of the $30 \% \mathrm{VBF}$ substituted bread were statistically the same with the $100 \%$ PVACF bread but differed in appearance (Table 6). The mean score of the sensory attributes decreases as VBF increased in the formulation. The result showed that up to $30 \%$ level of substitution of VBF with PVACF was acceptable for bread making while $50 \%$ VBF substituted bread was not acceptable. The mean scores of the sensory attributes of $30 \% \mathrm{VBF}$ substituted bread were statistically the same with $100 \%$ PVACF bread. The result of this research shows that VBF could be used in composite bread production at $30 \%$ level of substitution and beyond this level, bread characteristics may be affected. Similarly, the results of this study showed that as the amount of VBF increased to $50 \%$, bread was less acceptable.

\section{Conclusion}

Results obtained in this study showed that nutrientdense gluten-free bread could be produced from provitamin A cassava and velvet bean flour using Xanthan Gum as the binding agent. This study revealed that bread with comparable proximate composition and sensory attributes with $100 \%$ PVACF could be produced from up to $30 \%$ substitution of velvet beans. The presence of antinutritional factors identified in the current report should not pose a problem for humans as they fall within the acceptable limit. It can be deduced from this study that $50 \%$ inclusion of velvet beans in production of bread from PVACF is achievable.

Table 6. Organoleptic characteristics of PVACF/ VBF breads

\begin{tabular}{cccccc}
\hline Sample & Appearance & Aroma & Taste & Texture & Overall Acceptability \\
\hline A & $6.25 \pm 0.97^{\mathrm{a}}$ & $5.85 \pm 1.39^{\mathrm{a}}$ & $5.40 \pm 1.50^{\mathrm{ab}}$ & $4.85 \pm 1.43^{\mathrm{ab}}$ & $5.75 \pm 1.33^{\mathrm{a}}$ \\
B & $4.60 \pm 1.04^{\mathrm{c}}$ & $5.35 \pm 0.67^{\mathrm{a}}$ & $4.95 \pm 1.23^{\mathrm{bc}}$ & $5.55 \pm 1.57^{\mathrm{a}}$ & $5.15 \pm 1.09^{\mathrm{ab}}$ \\
C & $5.25 \pm 1.02^{\mathrm{b}}$ & $5.25 \pm 0.85^{\mathrm{a}}$ & $4.90 \pm 0.97^{\mathrm{bc}}$ & $4.90 \pm 1.29^{\mathrm{ab}}$ & $5.20 \pm 0.83^{\mathrm{ab}}$ \\
D & $5.50 \pm 0.69^{\mathrm{b}}$ & $5.25 \pm 0.85^{\mathrm{a}}$ & $5.80 \pm 1.57^{\mathrm{a}}$ & $5.65 \pm 1.27^{\mathrm{a}}$ & $5.70 \pm 1.08^{\mathrm{a}}$ \\
E & $4.45 \pm 1.00^{\mathrm{c}}$ & $4.35 \pm 1.42^{\mathrm{b}}$ & $4.40 \pm 1.27^{\mathrm{cd}}$ & $4.90 \pm 1.29^{\mathrm{ab}}$ & $4.80 \pm 1.44^{\mathrm{b}}$ \\
F & $3.25 \pm 1.16^{\mathrm{d}}$ & $3.50 \pm 1.57^{\mathrm{c}}$ & $3.65 \pm 1.14^{\mathrm{d}}$ & $4.15 \pm 1.09^{\mathrm{c}}$ & $3.45 \pm 1.15^{\mathrm{c}}$ \\
\hline
\end{tabular}

Means in the same column with the same superscript are not significantly different ( $\mathrm{p}>0.05)$. A $-100 \%$ PVACF, B - 90\%:10\% $\mathrm{PVACF} / \mathrm{VBF}, \mathrm{C}-80 \%: 20 \% \mathrm{PVACF} / \mathrm{VBF}, \mathrm{D}-70 \%: 30 \% \mathrm{PVACF} / \mathrm{VBF}, \mathrm{E}-60 \%: 40 \% \mathrm{PVACF} / \mathrm{VBF}, \mathrm{F}-50 \%: 50 \% \mathrm{PVACF} /$ $\mathrm{VBF}$, and $\mathrm{G}-100 \% \mathrm{VBF}$ 


\section{References}

Abou-Zaid, A.M., Mostafa, T.R. and AL-Asklany, S.A. (2011). Utilization of Faba Bean and Lupin Flours in Gluten Free Cake Production. Australian Journal of Basic and Applied Sciences, 5(12), 2665-2672.

Adebowale, A.A., Adegoke, M.T., Sanni, S.A., Adegunwa, M.O. and Fetuga, G.O. (2012). Functional properties and biscuit making potentials of sorghum-wheat flour composite. American Journal of Food Technology, 7(6), 372-379. https:// doi.org/10.3923/ajft.2012.372.379

AOAC. (2010). Official Methods of Analysis of the Association of Official Analytical Chemists. 18th ed., Washington DC, USA: AOAC.

Balogun, I.O. and Olatidoye O.P. (2012). Chemical composition and nutritional evaluation of velvet bean seeds (Mucunautilis) for domestic consumption and industrial utilization in Nigeria. Pakistan Journal of Nutrition, 11(2), 116-122. https:// doi.org/10.3923/pjn.2012.116.122

Bell, D.A. (1990). Methylcellulose as a structure enhancer in bread baking. Cereal Foods World, 35 (10), 1001-1006.

Brain, K.R. (1976). Accumulation of L-Dopa in cultures from Mucunapruriens. Plant Science Letters, 7(3), 157-161. https://doi.org/10.1016/0304-4211 (76) $90129-2$

Chan, H.T., Bhat, R. and Karim, A.A. (2009). Physicochemical and Functional Properties of Ozone -Oxidized Starch. Journal of Agricultural and Food Chemistry, 57, 5965-5970. https://doi.org/10.1021/ jf9008789

Fasano, A. and Catassi, C. (2001). Current approaches to diagnosis and treatment of Celiac disease: An evolving spectrum. Gastroenterology, 120(3), 636651. https://doi.org/10.1053/gast.2001.22123

Food and Agricultural Organization (FAO, 2005). Food Outlook - Biannual Report on Global Food Markets. Rome: FAO.

Giami, S.Y., Amasisi, T. and Ekiyor, G. (1992). Comparison of Bread Making Properties of Composite Flour from Kernels of Toasted and Boiled African Bread fruit (Treculia africandecne) seeds. Journal of Raw Materials Research, 1(1), 1625.

Ifesan, B.O.T., Akintade, A.O. and Gabriel-Ajobiewe, R.A.O (2017). Physicochemical and nutritional properties of Mucuna pruriens and Parkia biglobosa subjected to controlled fermentation. International Food Research Journal, 24(5), 2177-2184

Ikediobi, C.O., Onyia, G.O.C. and Eluwah, E.C. (1980). A rapid and inexpensive enzymatic assay for total cyanide in cassava and cassava products. Agricultural and Biological Chemistry, 44(12), 2803 -2809. https://doi.org/10.1271/bbb1961.44.2803

Inyang, U.E. and Ekop, V.O. (2015). Physico-Chemical Properties and Anti-nutrient Contents of Unripe Banana and African Yam Bean Flour Blends. International Journal of Nutrition and Food Sciences, 4(5), 549-554. https://doi.org/10.11648/ j.ijnfs.20150405.16

Janardhanan, K., Gurumoorthi, P. and Pugalenthi, M. (2003). Nutritional potential of five accessions of a South Indian tribal pulse, Mucuna pruriens var. utilis. Part I. The effect of processing methods on the contents of L-Dopa, phytic acid, and oligosaccharides. Journal of Tropical and Subtropical Agro-ecosystems, 1, 141-152.

Kumar, V., Makkar, H.P.S. and Becker, K. (2011). Detoxified Jatropha curcas kernel meal as a dietary protein source: Growth performance, nutrient utilization and digestive enzymes in common carp (Cyprinus carpio L.) fingerlings. Aquaculture Nutrition, 17(3), 313-326. https://doi.org/10.1111/ j.1365-2095.2010.00777.x

Latta, M. and Eski, M. (1980). A simple and rapid colorimetric method for phytate determination. Journal of Agricultural and Food Chemistry, 28(6), 1313-1315. https://doi.org/10.1021/jf60232a049

Lopez, A.C.B., Pereira, A.J.G. and Janqueira, R. G. (2004). Flour mixture of rice flour, corn and cassava starch in the production of gluten-free white bread. Brazilian Archives of Biology and Technology, 47 (1), 63-70. https://doi.org/10.1590/S151689132004000100009

Lorenzetti. F., MacIsaac, S., Arnason, J.T., Awang, D.V.C. and Buckles, D. (1998). The phytochemistry, toxicology and processing potential of the velvet bean (Mucunaaadans. spp., Fabaceae). In Buckles, D., Etèka, A., Osiname, O., Galiba, M. and Galiano, N. (Eds) Cover Crops in West Africa, p. 67-85. Ottawa, Canada: International Development Research Centre.

Makkar, H.P.S., Dawra, R.K. and Singh, B. (2006). Tannin levels in leaves of some oak species at different stages of maturity. Journal of the Science of Food and Agriculture, 54(4), 513-519. https:// doi.org/10.1002/jsfa.2740540403

Njoku, D.N., Egesi, C.N., Gracen, V.E., Offe, S.K., Asante, I.K. and Danquah, E.Y. (2014). Identification of Pro-Vitamin A Cassava (Manihot Esculenta Crantz) Varieties for Adaptation and Adoption through Participatory Research. Journal of Crop Improvement, 28, 361-376. https:// doi.org/10.1080/15427528.2014.888694 
Nwosu, J.N., Owuamanam, C.I., Omeire G.C. and Eke, C.C (2014). Quality parameters of bread produced from substitution of wheat flour with cassava flour using soybean as an improver. American Journal of Research Communication, 2, 99-118.

Olaoye, O.A., Onilude, A.A. and Idowu, O.A. (2006). Quality characteristics of bread produced from composite flours of wheat, plantain and soybeans. African Journal of Biotechnology, 5(11), 1102-1106.

Onwuka, G.I. (2005). Food Analysis and Instrumentation. Theory and Practice, p. 219-230. Surulere, Lagos, Nigeria: Naphthalic prints.

Shukla, K.K., Mahdi, A.A., Ahmad, M.K., Jaiswar, S.P., Shankwar, S.N. and Tiwari, S.C. (2007). Mucuna pruriens Reduces Stress and Improves the Quality of Semen in Infertile Men. Evidence Based Complementernative and Alternative Medicine, 7, 706982. https://doi.org/10.1093/ecam/nem171

Siddhuraju, P., Becker, K. and Makkar, H.P.S. (2000). Studies on the nutritional composition and antinutritional factors of three different germplasm seed materials of an underutilized tropical legume Mucuna pruriens var. utilis. Journal of Agriculture and Food Chemistry, 48, 6048-6060. https:// doi.org/10.1021/jf0006630

Singh, U. (2001). Functional properties of grain legume flours. Journal of Food Science and Technology, 38 (3), 191-199.

Torbica, A., Hadnadev, M. and Dapcevic, T. (2010). Rheological, textural and sensory properties of gluten-free bread formulations based on rice and buckwheat flour. Food Hydrocolloids, 24(6-7), 626632. https://doi.org/10.1016/j.foodhyd.2010.03.004

Vadivel, V. and Janardhanan, K. (2000). Nutritional and anti-nutritional composition of velvet bean: anunderutilized food legume in South India. International Journal of Food Sciences and Nutrition, 51(4), 279287. https://doi.org/10.1080/09637480050077167

Wahab, B.A., Adebowale, A.A., Sanni, S.A., Sobukola, O.P., Obadina, O.A., Kajihausa, O.E., Adegunwa, M.O., Sanni, L.O. and TomLins, K. (2016). Effect of species, pretreatments, and drying methods on the functional and pasting properties of high-quality yam flour. Food Science and Nutrition,4(1), 50-58. https://doi.org/10.1002/fsn3.260 